\title{
アミニルラジカルとアンモニウミルラジカルの化学
}

\section{小川桂一郎 ${ }^{*}$. 野 村 祐次郎 ${ }^{*}$}

\author{
Chemistry of Aminyl and Ammoniumyl Radicals
}

Keiichiro OGAWA* and Yujiro NomURA*

Generations, structures, and reactivities of aminyl and ammoniumyl radicals, especially the differences between these radicals, have been surveyed.

は じめに

アミニルラジカル (1) には簡単な発生法がなく, 立た 発生反応子限られているために, アルキルラシカルやア ルキルオキシルラジカルなどに較べて研究例が少なかっ た。しかし， 1970 年代の前半に Danen および Ingold ら によって集中的な研究が行われた結果, 基本的な性質に ついては一応理解されるようになり，その内容は 1975 年飞出された Danen と Neugebauer の総説 ${ }^{1}$ にくをと められている。その後のアミニルラシシカルに関する研究2,3) は非常に少なく, 未解明の問題はそのまま残されて現在 に至っている。

一方, アンモニゥミルラジカル (2) については, それ が合成反応の中間体としてしばしば登場するために, 合 成化学的な研究は多いが, 反応機構的な研究は比較的少 ないて6)

本総説では, ア、ニルラジカルとアンモニウミルラシ カルの発生法, 構造および反応性について概観し, とく に両者の性質の違いを明らかにするととに重点をおいた。 なお，乙てで扱うアミニルラジカルおよびアンモニウミ ルラシカルは, ヘテロ原子がラジカル中心の窒素に隣接 しないるのに限り，なだーアシルアミニルラシカルおよ びN-アシルアンモニウミルラジカルにつレて子省略した。
(1)<smiles>[R][N]</smiles>

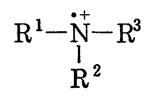

(2)
* 東京大学教養学部化学教室

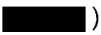

* Department of Chemistry, College of General Education, The University of Tokyo
1. 発 生 法

1. 1. アミニルラジカル 1911 年にWieland飞よっ て, テトラフェニルヒドラシンがトルエン中で熱的に解 離してジェニルアミニルシジカルの生成するととが確 められたのが, アミニルラジカルの最初の報告である゙。 以後, 次に列挙するよらな発生法が報告されている。

1）ヒドラジンの光または熱分解

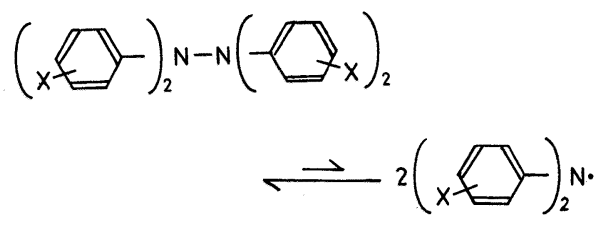

この平衡はヒドラシン側に片寄っており，Xが電子供 与基の場合にのみ $\operatorname{ESR} ゙$ でカルが検出された ${ }^{8,9)}$ 。テ トラアルキルヒドラジンからはアミニルラジカルは得ら れないが, シフルオロアミニルラジカルは二量体と平衡 にある10)。

$$
\mathrm{F}_{2} \mathrm{~N}-\mathrm{NF}_{2} \triangleq 2 \mathrm{~F}_{2} \mathrm{~N} \text {. }
$$

2) テトラゼンの光をたは熱分解 ${ }^{11 〜 3)}$

$$
\mathrm{R}_{2} \mathrm{~N}-\mathrm{N}=\mathrm{N}-\mathrm{NR}_{2} \longrightarrow 2 \mathrm{R}_{2} \mathrm{~N} \cdot+\mathrm{N}_{2}
$$

アミニルラジカルの最もをれいな, そして一般的な発 生法であるが，テトラゼンの合成がやっかいである。

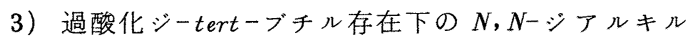
アミド亜リン酸ジチルの光分解 ${ }^{14)}$

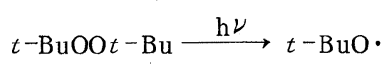

$t-\mathrm{BuO} \cdot+\mathrm{R}_{2} \mathrm{NP}(\mathrm{OEt})_{2} \rightarrow t-\mathrm{BuOP}(\mathrm{OEt})_{2}+\mathrm{R}_{2} \mathrm{~N} \cdot$

テトラゼンの光分解よりも低温で, 高濃度のアミニル ラジカルが得られる。また原料合成もテトラゼンよりる 容易である。 
4）ヒドロキシルラシカカルをはtertーブトキシルラ シカルによるアミンの $\mathrm{N}-\mathrm{H}$ 水素の引抜を反応 アシシシシと過酸化ジ-tert-プチルのシクロプロパン 溶液に， -100 C で光照射するとと飞より，1-アシリシニ ルラฺシカル（3）のESRスペクトルが得られた。同様にし て1ーアゼチシシルラシシカル(4) の ESRスペクトルも得 られている15)。

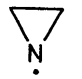

(3)

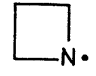

(4)
また，2-アミノー2-メチルプロパン酸に, $\mathrm{pH} 13$ て $\mathrm{H}_{2} \mathrm{O}_{2} / \mathrm{Ti}^{3+}$ Kよって生じたヒドロキシルラジカルを作用 させると，ラシカカ（5) ととるにアミニルラジカル(6) が生じる16)。<smiles>CC(C)(N)C(=O)[O-]</smiles>

(5)<smiles>CC(C)(N)C(=O)[O-]</smiles>

(6)
5）アミンへの光，X線をたは $\gamma$ 線照射

ピロリシンのアダマンタンマトリックスにX線照射17), アニリンのアダマンタンマトリックス $氏 r$ 線照射 ${ }^{18)}, 2$, 4,6 -トリ-tertーブチルアニリンの閃光分解 ${ }^{19,20)}$ あるい はアンモニアのアルゴンマトリックスに光照射11)するこ とによって, それぞれ対応するアミニルラジカルが得ら れている。

6） Nークロロアミンの光分解または銀 (I) イオンない

し金属銀を触媒とする分解<smiles>CCCCCCC1(C)CCCC(C)(C)N1[Te]</smiles>

$\mathrm{R}_{2} \mathrm{NCl}+\mathrm{AgO} \stackrel{23,24)}{\longrightarrow} \mathrm{R}_{2} \mathrm{~N} \cdot+\mathrm{AgCl}$ $N$-クロロアミンのメタノール中の光分解では, へテロ リシスる部分的に起とっているととが最近報告された ${ }^{25)}$ 。

7) ペルオキシカルバミド酸 tert-ブチルの熱分解

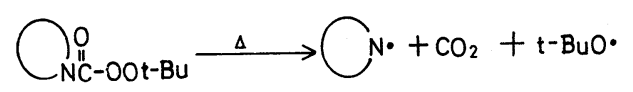

1 -ピロリジニルラジカル ${ }^{26)}$ や, cis-2, 3-ジフェニルー 1ーアシシシニルラジカル $(8)^{27)}$ などがての方法により生 じている。

8） $N$-ニトロアミンの中性メタノール中での光分解 ${ }^{28)}$ 酸性条件では, ピペリジニウムミルラジカルが生成す る。

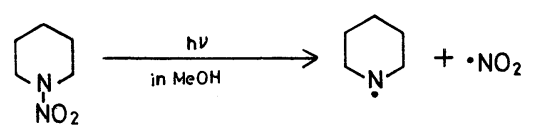

9) ピロール類の酸化銀 $\left(\mathrm{Ag}_{2} \mathrm{O}\right)$, 二酸化鉛 $\left(\mathrm{PbO}_{2}\right)$, ヘキサシアノ鉄 (III) 酸カリウム $\left(\mathrm{K}_{3}\left[\mathrm{Fe}(\mathrm{CN})_{6}\right]\right)$, 臭素またはヨウ素による酸。化1,29)<smiles>c1ccc(-c2ccccc2-c2ccccc2-c2ccccc2)cc1</smiles>

(9)

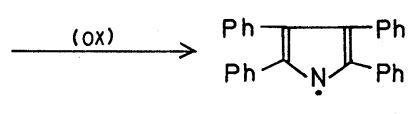

(10)
テトラフェニルピロールの場合, 生じたラジカルは容 易に二量化し，二量体が結晶として得られるが，てれを 光照射あるいは加熱すると解離してもとのラジカル(10) を生ずる。

10）アルカリ性水溶液中におけるピロリシンの銀 (I) 塩存在下のペルオキソ三硫酸塩による酸化 30 )

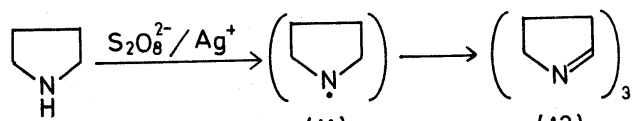

(11)

(12)

ピロリシンを上記の条件で酸化すると，1ーピロリン三 量体（12）のみが選択的飞生成するが，乙れはおそらく途 中に1-ピロリシニルラシカル(11)を生成しているものと 考えられる。乙れは, 最す容易な1ーピロリシニルラジカ ルの新しい発生法といえる。

1. 2. アンモニゥミルラジカル アンモニウミルラ シカルの発生法は, アミニルラジカルにくらべてはるか に容易である。以下今までに知られている発生法を列挙 する。

1）アンモニウム塩へのX線をたは $\gamma$ 線照射

$\mathrm{NH}_{4} \mathrm{ClO}_{4}{ }^{31}{ }^{32)}, \mathrm{Me}_{4} \mathrm{NCl}^{33)}$ 亿室温でX線をたは $\gamma$ 線を照 射して，それぞれ $\dot{\mathrm{NH}}_{3}$ および $\mathrm{Me} \dot{+}$ の $\mathrm{ESR}$ スペクトルが測 定されている。

2）酸性溶媒中でのN-クロロアミンの光分解

$$
\mathrm{R}_{2} \mathrm{~N} \underset{90 \% \mathrm{H}_{2} \mathrm{SO}_{4} \text { 中 }}{\stackrel{h \nu}{\longrightarrow}} \mathrm{R}_{2} \stackrel{+}{\mathrm{NH}}
$$

Danenらはこの方法により，一連のジアルキルアンモ ニウミルラジカルの ESRスペクトルを測定した ${ }^{34)}$ 。

3）酸性溶媒中でのN-クロロアミンのラジカル開始剤 による分解

開始剤として， $\alpha, \alpha^{\prime \prime}$-アゾジイソブチロニトリル（AI

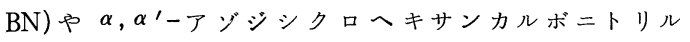
$(\mathrm{ACHN})$ などが用いられる35)。

4）酸性溶媒中でのNークロロアミンの金属イオンによ 
る 還元 ${ }^{4 \sim 6)}$

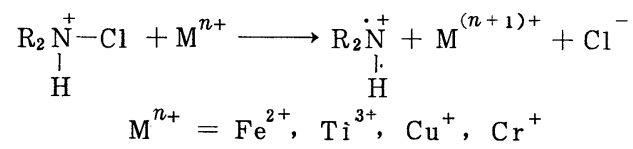

5）酸性溶媒中でのヒドロキシルアミンおよびヒドロ キシルアミンOースルホン酸の金属イオンによる還 元 $^{4 \sim 6)}$

$\mathrm{NH}_{2} \mathrm{OH}+\mathrm{Ti}^{3+}+\mathrm{H}^{+} \longrightarrow \dot{\mathrm{NH}}_{3}+[\mathrm{TiOH}]^{3+}$

$\mathrm{H}_{3} \mathrm{~N}^{+}-\mathrm{OSO}_{3}^{-}+\mathrm{Fe}^{2+} \longrightarrow \dot{\mathrm{N}}_{3}^{+}+\mathrm{Fe}^{3+}+\mathrm{SO}_{4}^{2-}$

6）酸性溶媒中でのアミンォキシドの金属イオンによ る還元 ${ }^{36 \sim 38)}$

$\mathrm{R}_{3} \mathrm{~N} \rightarrow \mathrm{O}+\mathrm{Fe}^{2+}+2 \mathrm{H}^{+} \longrightarrow \mathrm{R}_{3} \stackrel{+}{\mathrm{N}}+\mathrm{Fe}^{3+}+\mathrm{H}_{2} \mathrm{O}$

7）酸性溶媒中での $N$-ニ゙トロソアミンおよびN-ニトロ アミンの光分解 $\left.{ }^{28}, 39,40\right)$

$$
\begin{aligned}
& \mathrm{R}_{2} \mathrm{~N}-\mathrm{NO}+\mathrm{H}^{+} \stackrel{\mathrm{h} \nu}{\longrightarrow} \mathrm{R}_{2} \stackrel{\stackrel{+}{\mathrm{H}}}{ }+\cdot{ }^{\circ} \mathrm{NO} \\
& \mathrm{R}_{2} \mathrm{~N}-\mathrm{NO}_{2}+\mathrm{H}^{+} \stackrel{\mathrm{h} \nu}{\longrightarrow} \mathrm{R}_{2} \stackrel{+}{\mathrm{N}}+\cdot \mathrm{NO}_{2}
\end{aligned}
$$

8) アミンの電気化学的酸化 $\left.{ }^{41}, 42\right)$

$$
\begin{aligned}
& \mathrm{RCH}_{2} \mathrm{NH}_{2} \longrightarrow \mathrm{RCH}_{2} \stackrel{+}{\mathrm{NH}}_{2}+e^{-} \\
& \left(\mathrm{XC}_{6} \mathrm{H}_{4}\right)_{3} \mathrm{~N} \longrightarrow\left(\mathrm{XC}_{6} \mathrm{H}_{4}\right)_{3} \stackrel{+}{\mathrm{N}}+e^{-}
\end{aligned}
$$

9）トリフルオロ酢酸中におけるジリールアミンの 四酢酸鉛に上る酸化 $\left.{ }^{43}\right)$

$$
\mathrm{Ar}_{2} \mathrm{NH}+\mathrm{H}^{+} \stackrel{\mathrm{Pb}(\mathrm{OAc})_{4}}{\longrightarrow} \mathrm{Ar}_{2} \dot{\mathrm{NH}}^{+}
$$

10） $N, N^{\prime}$-ジメチルアニリンと過酸化ジアシルとの反 応 $^{44)}$

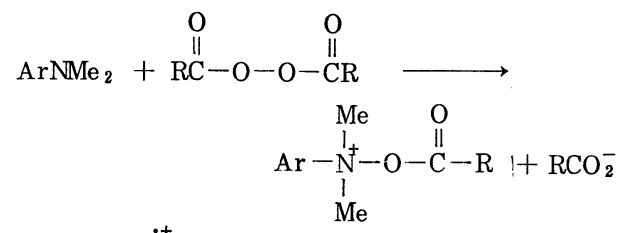

$\mathrm{Ar}^{\mathrm{N} M e}{ }_{2}+\mathrm{RCO}_{2} \cdot+\mathrm{RCO}_{2}^{-}$

$\mathrm{Ar}-\underset{l}{\stackrel{\mathrm{N}^{+}}{=} \mathrm{CH}_{2}+\mathrm{RCO}_{2} \mathrm{H}+\mathrm{RCO}_{2}^{-}}$

これはアンモニウミルラジカルを得る目的で使われる

反応ではないが, とにかくアンモニウミルラジカが発 生するというととであげておいた。

酸性溶媒中でのテトラゼンの光または熱分解によって も, アンモニウミルラジカルは発生すると思われるが， そのような報告はない。

\section{2. 構造}

アミニルラジカルおよびアンモニウミルラジカルの構
造については，それを確立したDanen 自身によるすぐれ た総説1)があるので，てとではごく簡単に触れるにとど める。

アミニルラシカルは，ラシカル中心に非共有電子対と 不対電子の両方をつので, 基底状態において不対電子 が $\mathrm{p}$ 軌道に入らる $\pi$-ラシカルか, $\mathrm{sp}^{2}$ 軌道に入らる $\sigma$ ラジカルかの二通りの可能性がある。ESRによる研究 およびINDO法にょる計算から, 現在ではシアルキルア ミニルラジカルはすべて れている り, 非共有電子対は $\mathrm{sp}^{2}$ 軌道に, 不対電子が $\mathrm{p}$ 軌道に入 いっている構造である。1-アシシリジニルラジカル（3)に おいても, 不対電子が純粋な $\mathrm{p}$ 軌道に入らっている ${ }^{15)}$ は, シクロプロピルラシカルの中心炭素がピラミド型で あるのと対照的である ${ }^{45)}$ 。

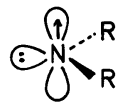

$\pi$ ラシジカ

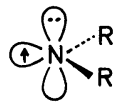

$\sigma$-ラジカル

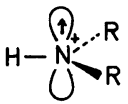

(13)
シアルキルアミニルラジカルの共役酸であるジルキ ルアンモニゥミルラシカカ（13） も, 同様に $\pi$ ーラジカル であるととが, やはり Danenらの ESRの研究とょり明ら かにされている。

ジルキルアミニルラシカルが $\pi$ シシシカルであるてと は, ラジカルの塩基性度からも示唆されている。ジメチ ルアミニルラジカル (14) の共役酸 (15)の $p K a$ は $7.0 \pm$ 0.5 と求められているが46)，乙の值をジメチルミンの 共役酸（17）の $p K a=10.7$ と比較すると，(15)の方が (17)ょりも酸性度の大をいととがわかる。とれは, アミ ニルラジカルの非共有電子対の軌道（㴗 $\mathrm{sp}^{2}$ )の $\mathrm{s}$ 性 がアミンの非共有電子対の軌道（活 $\mathrm{sp}^{3}$ )の $\mathrm{s}$ 性より も大をいととを示するのである。
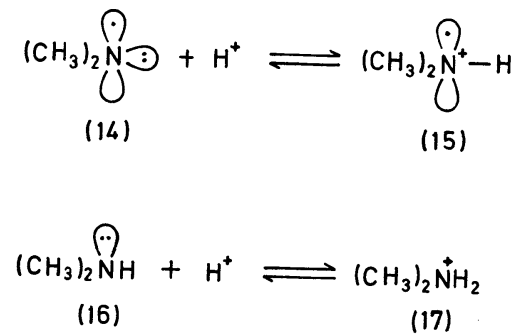

一方アリールアミニルラシカルでは, ジルキルアミ ニルラジカルに較べて事情はやや複雑である。フェニル 基につんた置換基がラジカル中心の不対電子密度に及医 す影響の仕方には，次の二通りの可能性が考えられる。 
第一の場合には，フェニル基についた置換基が電子供与 性か電子求引性かにかかわらず, 不対電子を非局在化す る場合で, どちらのタイプの置換基も窒素原子上の不対 電子密度を減少させる。とのような挙動をするラジル

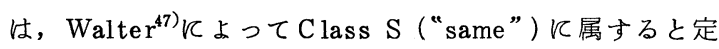
義された。第二の場合は, フェニル基についた置換基が 電子供与性のとをには不対電子が非局在化されるが, 電 子求引性のとをには非共有電子対が非局在化される場合 である。この場合, 窒素原子上の不対電子密度は電子供 与基によって減少し, 電子求引基によって增加するとと になり、こらした挙動をするラシカルをWalter はClass O (“opposite”)のラシカルと定義した。ESRによる研究 から, 今までに知られているアリールアミニルラシカル はすべてClass Sのラシカルであり, 従って であるととが結論されている1。

アリールアンモニウミルラジカルでは, 非共有電子対 は窒素原子上飞ないから, 明らかにClass S ルである゙7)。

\section{3. 反応性}

アミニルラジカルとアンモニウミルラジカルの行う反 応を, アミニルラシカルと等電子的構造をるつアルキル オキシルラジカルのてれと対比してみたのが表 1 である

Table 1 A comparison of the reactivities of aminyl $\mathrm{R}_{2} \mathrm{~N}$ 。 and ammoniumyl $\mathrm{R}_{2} \dot{\mathrm{NH}}$ radicals with those of alkyloxyl radicals ${ }^{a}$ )

\begin{tabular}{l|ccc}
\hline \multicolumn{1}{c|}{ Reaction } & $\mathrm{RO} \cdot$ & $\mathrm{R}_{2} \mathrm{~N} \cdot$ & $\mathrm{R}_{2} \mathrm{~N}^{\mathrm{NH}}$ \\
\hline 1) Bimolecular radical association & $\bigcirc$ & $\bigcirc$ & $\bigcirc$ \\
2) Fragmentation & $\bigcirc$ & $\times$ & $\bigcirc$ \\
3) Rearrangement (1,5-hydrogen shift) & $\bigcirc$ & $\times$ & $\bigcirc$ \\
4) Hydrogen abstraction & $\bigcirc$ & $\bigcirc$ & $\bigcirc$ \\
5) Di splacement & $\bigcirc$ & $\bigcirc$ & $\times$ \\
6) Addition & $\bigcirc$ & $x^{b)}$ & $\bigcirc$ \\
\hline
\end{tabular}

a) $\bigcirc$ and $x$ denote reactive and unreactive, respectively.

b) It is reactive in some cases.

アミニルラジカルの行ら代表的な反応は, 会合量化 と不均化, 水素引き抜を反応および有機金属化合物の中 心金属上での $\mathrm{SH}_{2}$ (Bimolecular homolytic substitution) 反応であり, 開裂反応山行わず, 分子内 1,5 水素移動お よび孤立炭素一炭素二重結合ないしベンゼン環に対する 付加反応子通常行わないとされている。不飽和結合一付 加せず, 水素引き抜ををしやすいのは, アルキルオキシ ルラシカルに似ているといえる。また有機金属化合物の 中心金属上て S 2 反応をするてともアルキルオキシルラ シカルに似ている。てれに対し, アミニルラジカルがプ
ロトン化したアンモニウミルラジカルになると, その反 応性はがらりと変わって, 開裂反応や転移反応を行らよら になり,さらに不飽和結合に対する付加活性が, 水素引を 抜を活性に較べて圧倒的に高くなる。通常化学的に最も 簡単にアミニルラジカルとアンモニウミルラジカルを区 別するのに, この不飽和結合への付加活性が判定の根拠 となるほどである。以下, 表 1 の項目に沿って, アミニ ルラシカルおよびアンモニウミルラジカルの反広を, ア ルキルオキシルラジカルのそれと比較しながら述べてみ よう。

3.1. ラジカル間の結合反応他の反応物が存在し ないとをには、シメチルアミニルラジカル（14）は会合 二量化してヒドラシン（18）を生成すると同時に, 不均 化によってメチレンイミン (19) とシシメチルアミン (16) を生成する ${ }^{11,12,48)}$ 。メチレンイミン (19)は,さらに反応 して三量体やポリマーを与える。

$$
\left(\mathrm{CH}_{3}\right)_{2} \mathrm{~N}-\mathrm{N}\left(\mathrm{CH}_{3}\right)_{2} \longleftarrow 2\left(\mathrm{CH}_{3}\right)_{2} \mathrm{~N} \text {. }
$$

$$
\begin{gathered}
\left(\mathrm{CH}_{3}\right)_{2} \mathrm{NH} \\
(16)
\end{gathered}+\quad+\quad\left(\mathrm{H}_{2} \mathrm{C}=\mathrm{N}-\mathrm{CH}_{3}\right)
$$

シメチルアミニルラジカルの結合反応の反応速度定数 は, アルキルオキシルラシカルのそれと医等しく, 拡 散律速の程度 $\left(2 \times 10^{9} \mathrm{~m} \mathrm{ol}^{-1} \mathrm{l} \mathrm{s}^{-1}\right)$ である ${ }^{48,49)}$ 。従っ て, シメチルアミニルラジカルでは, 咥素の非共有電子 対の間の反発は小さいと思われる。

不均化と会合二量化は, シメチルアミニルラジカルの 場合, 汪同じ割合で起てる。しかし, 立体障害が大を くなるにつれて会合二量化はしにくくなり, シィソプロ ピルアミニルラジカルでは不均化のみがゆっくり起てる ようになる（ $\left.1 \times 10^{7} \mathrm{~mol}^{-1} \mathrm{l} \mathrm{s}^{-1}\right)$ 。立体障害が大をく, かつ $\alpha$ 水素のない $2,2,6,6$-テトラメチルー1ーピペリシニ ルラシカル (7) は, 無酸素䨌囲気下では安定である ${ }^{48)}$ 。

相異なるアミニルラジカル間の結合反応についての報 告はない。

一方, アンモニウミルラシシカルについては, Ingoldら の速度論的研究から, 酸性溶媒中においてシメチルアン モニウミルラジカルあるいは1-ピペリシニウムラジカル が会合するととが結論されており，会合の絶対反応速度 定数は $6 \times 10^{6} \sim 5 \times 10^{7} \mathrm{~mol}^{-1} 1 \mathrm{~s}^{-1}$ と求められてい る ${ }^{35)}$ 。しかし，生成物の構造は確認されていない。

パラ位に置換基のないアリールアンモニゥミルラシカ ルの場合には, 炭素一炭素カップリングをしてベンジシ ンが生成する ${ }^{42)}$ 


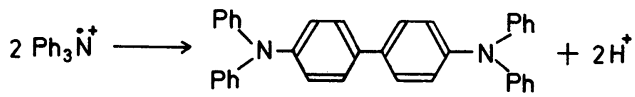

3.2. 開裂反応 アルキルオキシルラシカルは容易 に $\beta$-開裂をして,アルキルラジカルとアルデヒドまたは ケトンを与えるが，アミニルラジカルの開裂反応は知ら れていない。一方，アンモニウミルラシカカルについては， $\beta$ 一開裂が報告されている

$$
\begin{aligned}
& \mathrm{C}_{6} \mathrm{H}_{5}-\mathrm{CH}_{2}-\mathrm{CH}_{2}-\stackrel{+}{\stackrel{+}{\mathrm{N}}}-\mathrm{CH}_{3} \\
& \longrightarrow \mathrm{C}_{6} \mathrm{H}_{5} \mathrm{CH}_{2} \cdot+\underset{\mathrm{l}}{\mathrm{C}} \stackrel{\stackrel{+}{\mathrm{N}}-\mathrm{CH}_{3}}{\stackrel{\mathrm{C}}{\mathrm{C}}}
\end{aligned}
$$

3.3. 転移反応 アルキルオキシルラシカカは, 六員環遷移状態を経て分子内 1,5-水素移動するが, アミ ニルラジカルの例は知られていない。これに対しアンモ ニウミルラシカルの分子内 1,5-水素移動は, Hof mannLöffler 反応として，とくに天然物合成に用いられてき た。これは酢酸一硫酸混合溶媒中で, $N$-クロロアミンに 光照射をたは金属塩（主に $\mathrm{FeSO}_{4}$ )を作用させたのち, 塩基で処理してピロリジンを生成する反応で，次のよう な機構で進行するすのと考えられている51。

$$
\begin{aligned}
& \mathrm{R}_{2} \mathrm{~N}-\left(\mathrm{CH}_{2}\right)_{3}-\mathrm{CH}_{3}+\mathrm{Fe}^{2+}+2 \mathrm{H}^{+} \\
& \downarrow
\end{aligned}
$$

$$
\mathrm{R}_{2} \stackrel{+}{\mathrm{N}}-\left(\mathrm{CH}_{2}\right)_{3}-\mathrm{CH}_{3}+\mathrm{Fe}^{3+}+\mathrm{H}_{2} \mathrm{O}
$$$$
\mathrm{R}_{2} \stackrel{+}{\mathrm{N}}-\left(\mathrm{CH}_{2}\right)_{3}-\mathrm{CH}_{3} \longrightarrow \mathrm{R}_{2} \stackrel{+}{\mathrm{N}} \mathrm{H}-\left(\mathrm{CH}_{2}\right)_{3}-\dot{\mathrm{C}} \mathrm{H}_{2}
$$

アミニルラジカルの転移反応としては， 1,2 -水素移動 および 1,3 一水素移動が報告されている ${ }^{48,55,56) 。 ~}$

3.4. 水素引き抜き反応 アミニルラシカルの水素 引き抜き能力は小さく, ベンジル水素やアリル水素など の活性水素しか引き抜かない年 59)。しかし，会合反応を しにくレ2,2,6,6 -テトラメチルピペリシニルラシカル

（7）では，水素引き抜を活性は高く，種々の溶媒から水
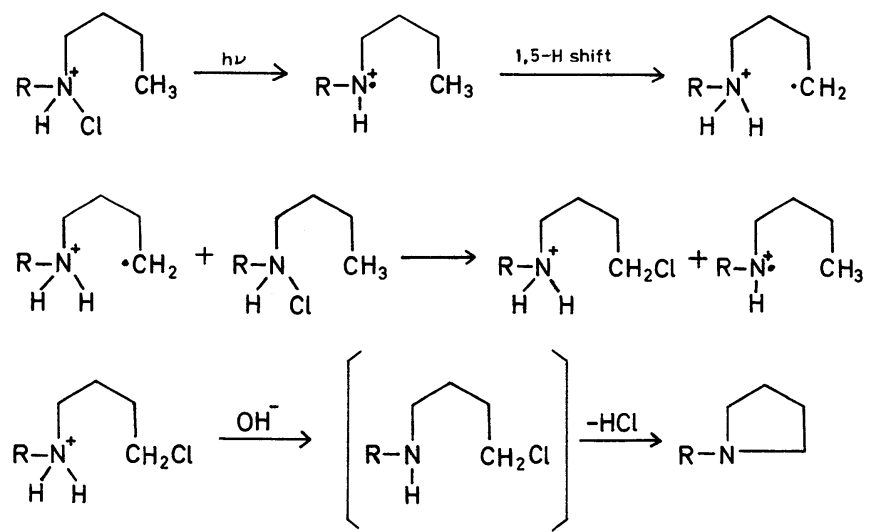

素を引き抜く。トルエンからの水素引き抜 き反応の反応速度定数は, $0.69 \mathrm{~mol}^{-1} 1 \mathrm{~s}^{-1}$ $\left(24{ }^{\circ} \mathrm{C}\right)$ であり，てれはtertーブチルペル オキシルラシカルやベンジル゚ルオキシル ラシカルよりる大をい潘。しかし，アルキ ルオキシルラジカルに較べればはるかに小 さく，約 $10^{-5}$ 倍である60)。

一方アンモ二ウミルラジカルのシクロへ キサンからの水素引き抜を反応の反応速度 定数は, シメチルアンモニウミルラシカル およびピペリジゥムラジカルについて 2 $\times 10^{3} \sim 3 \times 10^{4} \mathrm{~mol}^{-1} \mathrm{js}^{-1} \quad\left(30^{\circ} \mathrm{C}\right)$ と求 められている35)。シクロへキサンからの

Hofmann-Löffler反応については多くの総説がある゙， $6,52 \sim 55)$ 。

Hofmann-Löf fler 反応以外のアンモニウミルラシカル の転移反応の例としては, 複素芳香族塩基の丁ミノテル キル化をあげるととができる。これは，アンモニウミル ラジカルの分子内 1,5 -水素移動によって生じたアミノア ルキルラシカルが求核性を有し, プロトン化された複素 芳香族塩基飞効率よくトラップされるととを利用したも ので，次のよらな反応機構が考えられている ${ }^{38)}$ 。 tertーブトキシルラジカルの水素引抜を反応の速度定 数は〜 $1 \times 10^{5} \mathrm{~mol}^{-1} 1 \mathrm{~s}^{-1}$ であるから ${ }^{60)}$, アンモ二ウ ルラシカルの水素引き抜き活性は, アミニルラシカルの

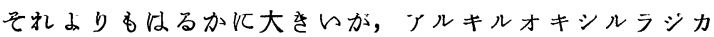
ルよりる少し小さいととがわかる。

長い炭素鎖をるつアンモニウミルラシカルでは，分子 内水素引抜を反応（ 1,5 - 水素移動）と分子間水素引 き抜を反応が競争的に起てるが30, 61)，Hofmann-Löffler 反応をみれば明らかなように，分子内水素引を抜を反応の 
方が優先して起こる。アルキルオキシルラシカルにおい

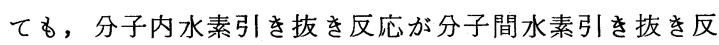
応や $\beta$-開裂よりるずっと優先して起こる ${ }^{62,63) 。 ~}$

さて, アンモニウミルラジカルの水素引き抜を反応に ついて特記すべをととは, 濃硫酸中における反応におい て水素引抜きの選択性が非常飞高いととである。Mi一 nisci らは, 濃硫酸中に和いて, Hofmann-Löffler 反庎 を行わない炭素鎖の短いアンモニウミルラシカルが, 電 子求引基をつ飽和化合物の（ $\omega-1$ ）位（鎖端から 2 番 目)の水素を，選択的に引を抜くととを見出した ${ }^{5)}$ 。乙 れを利用して，長鎖 $\left(\mathrm{C}_{5} \sim \mathrm{C}_{8}\right)$ のアルコール，エーテル， カルボン酸, エステル, アミト゚ならびにハロゲン化アル キルは，96\%硫酸中で硫酸鉄（II）の存在下に $N$-ク口ロ アミンを作用させるととにょり，( 収率よく塩素化されるが，乙れは次の上うな機構で進行 している。

$$
\begin{aligned}
& \sum_{\mathrm{R}}^{\mathrm{R}} \underset{\mathrm{H}}{\mathrm{N}^{+} \mathrm{Cl}}+\mathrm{Fe}^{2+} \longrightarrow \sum_{\mathrm{R}}^{\mathrm{R}} \underset{\mathrm{H}}{\stackrel{+}{\mathrm{N}}}+\mathrm{Fe}^{3+}+\mathrm{Cl}^{-}
\end{aligned}
$$

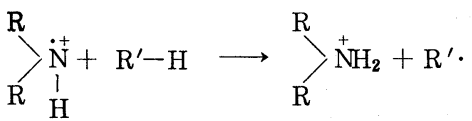

$$
\begin{aligned}
& \mathrm{R}^{\prime} \cdot+\sum_{\mathrm{R}}^{\mathrm{R}} \underset{\mathrm{H}}{\stackrel{+}{\mathrm{N}}-\mathrm{Cl}} \longrightarrow \mathrm{R}^{\prime}-\mathrm{Cl}+\sum_{\mathrm{R}}^{\mathrm{R}} \stackrel{\circ}{\mathrm{N}_{\mathrm{H}}^{+}}
\end{aligned}
$$

また，へキシルアミンとNークロロジメチルミンから のピペリシン類の生成も, 巧みな応用例である ${ }^{64)}$ 。

\section{$\mathrm{CH}_{3}\left(\mathrm{CH}_{2}\right)_{5} \mathrm{NHR}+\mathrm{Me}_{2} \mathrm{NCl}$}

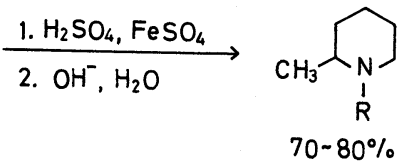

$N$-クロロヘキシルアミンの Hofmann-Löffler 反応か らはピロリジンのみが生成するのと対照的である。ての 反応の機構は次のように考えられる。

$$
\begin{aligned}
& \mathrm{Me}_{2} \underset{\mathrm{H}}{\stackrel{+}{\mathrm{NC}} 1}+\mathrm{Fe}^{2+} \longrightarrow \mathrm{Me}_{2} \underset{\mathrm{H}}{\stackrel{+}{\mathrm{N}}}+\mathrm{Fe}^{3+}+\mathrm{Cl}^{-} \\
& \mathrm{CH}_{3}\left(\mathrm{CH}_{2}\right)_{5} \stackrel{+}{\stackrel{+}{\mathrm{N}_{2}}}+\mathrm{Me}_{2} \underset{\mathrm{R}}{\stackrel{+}{\mathrm{N}}} \longrightarrow
\end{aligned}
$$

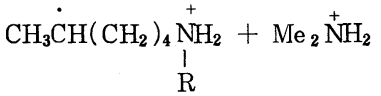

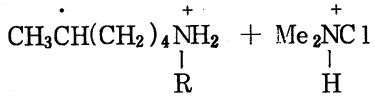

$$
\begin{aligned}
& \longrightarrow \mathrm{CH}_{3} \mathrm{CHCl}\left(\mathrm{CH}_{2}\right)_{4} \underset{\mathrm{l}}{\stackrel{+}{\mathrm{N}}} \mathrm{l}_{2}+\mathrm{Me}_{2} \stackrel{\bullet+}{\mathrm{N}}
\end{aligned}
$$

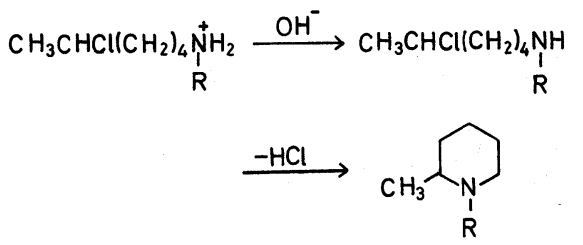

次亜塩素酸 $t$ ert ーブチルと $N$-クロロアミンの飽和炭化 水素に対する反応熱はほほ同じであるのに，tertーブト キシルラシカルによる水素引を抜をは非選択的であり， アンモニウミルラシカルによるそれが選択的であるのは, カチオンラジカルの方が中性ラジカルりる極性効果に 敏感なためと考えられる ${ }^{35)}$ 。極性効果のためにてのよう な高い選択性を有するラジカルは, アンモニウミルラシ カル以外には知られていない゙38。

\section{5. 置換反応了ミニルラシカルは有機金属化合} 物の中心金属上て $\mathrm{S}_{\mathrm{H}} 2$ 反応を行う。たとえば,トリブチ ルボラン存在下にテトラメチルテトラゼンを光分解する と, ブチルラジカルの ESRスペクトルが観測され, シブ チルーN, $N$-ジメチルアミノボランとオクタンが主生成 物となる ${ }^{65)}$ 。

$$
\begin{gathered}
\mathrm{Me}_{2} \mathrm{~N}-\mathrm{N}=\mathrm{N}-\mathrm{NME}_{2} \quad \stackrel{\mathrm{h} \nu}{\longrightarrow} \mathrm{N}_{2}+2 \dot{\mathrm{Me}}_{2} \mathrm{~N} \cdot \\
\mathrm{Me}_{2} \mathrm{~N} \cdot+\mathrm{BBu}_{3} \longrightarrow \mathrm{Me}_{2} \mathrm{NBBu}_{2}+\mathrm{Bu} \cdot \\
2 \mathrm{Bu} \longrightarrow \mathrm{Bu}-\mathrm{Bu}
\end{gathered}
$$

また, シメチルアミニルラジカルを $N$ ークロロジメチル アミンから発生させた場合には, 置換反応によって生じ たアルキルラジカルが塩素を引を抜いて, シメチルアミ ニルラジカルを再生するととになる ${ }^{66)}$ 。

$$
\begin{aligned}
& \mathrm{Me}_{2} \mathrm{~N} \cdot+\mathrm{BBu}_{3} \longrightarrow \mathrm{Me}_{2} \mathrm{NBBu}_{2}+\mathrm{Bu} \cdot \\
& \mathrm{Bu}+\mathrm{Me}_{2} \mathrm{NCl} \longrightarrow \mathrm{BuCl}+\mathrm{Me}_{2} \mathrm{~N} .
\end{aligned}
$$

アルキルオキシルラシカルる同じ型の反応を行 $5^{67)}$ 。 過酸化ジーtertーブチルを用いた場合には；

$$
\begin{aligned}
& t-\mathrm{BuOO} t-\mathrm{Bu} \stackrel{\mathrm{h} \nu}{\longrightarrow} 2 t-\mathrm{BuO} \cdot \\
& t-\mathrm{BuO} \cdot+\mathrm{BBu}_{3} \longrightarrow t-\mathrm{BuOBBu}_{2}+\cdot \mathrm{Bu}
\end{aligned}
$$

次亜塩素酸 $t$ ertーブチルを用いた場合には；

$$
\begin{aligned}
& t-\mathrm{BuO}^{\circ}+\mathrm{BR}_{3} \longrightarrow t-\mathrm{BuOBR}_{2}+\mathrm{R} \cdot \\
& \mathrm{R} \cdot+t-\mathrm{BuOC} 1 \longrightarrow \mathrm{RC} 1+t-\mathrm{BuO} .
\end{aligned}
$$


アミニルラジカルとグリニャール試薬, 有機水銀化合 物, あるいは有機アルミニウム化合物との反応も報告さ れている ${ }^{67,68)}$ 。

てのようにアミニルラジカはアルキルオキシルラシ カルと同じょうに，有機金属化合物の中心金属上で $\mathrm{SH} 2$ 反応をするが，アンモニウミルラジルの例は知られて いない。

3.6. 付加反応 アミニルラジカルは一般に, 孤立 炭素一炭素二重結合には付加しないとされているが28,57 -69,69), 乙れは，アルキルオキシルラシカルルおいて水 素引を抜き反応が付加反応よりすずっと有利に起てるの に似ている。

$\mathrm{Ab}$ initio 法による計算からは, アミニルラジカルの 窒素の非共有電子対とオレフィン中心との間に反発的相 互作用のあるととが示されており，乙れがアミニルラシ カルがオレフィンに付加しないととの原因であろうと考 えられている。計算によると， $\mathrm{NH}_{2}$ のエチレンへの付加 の活性化エネルギーは35〜 40 kcal $/ \mathrm{mol}$ である ${ }^{74)}$ 。

しかしながら，アミニルラシカルが孤立炭素－炭素二 重結合に付加するといら報告も二報だけ出ている。一つ は, シメチルアミニルラジカルのエチレンに対する付加 であり ${ }^{70)}$ ，す5一つは中性溶媒中（メタノール，インプ ロピルアルコール)におけるN-クロロアミン (20)の光分 解によって, 環状アミン（21）が主生成物になるといらす のである<smiles>C=CCCCN(Cl)Cl</smiles>

(20)

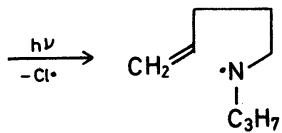<smiles>CCCCC1CCCN1CCCC</smiles><smiles>CCCN1CCCC1CO</smiles>

(21)

一方, アンモニウミルラジカルのオレフィンへの付加 反応性は, 競争的に起てる水素引き抜き反応に比へて非 常飞高い。Chow らは， $N$-ニトロソピペリシンの酸性溶 媒中での閃光分解から，ピペリシニウミルラジカルのシ クロへキセンに対する付加反応の速度定数 $k_{1}$ 老 $2.4 \times 10^{7}$ $\mathrm{mol}^{-1} 1 \mathrm{~s}^{-1}$ と求め, メタノールからの水素引を抜を反応 の速度定数 $k_{2}$ との間に $k_{1} \approx 5000 k_{2}$ であるととを報告して
レろ ${ }^{39 *)}$ 。
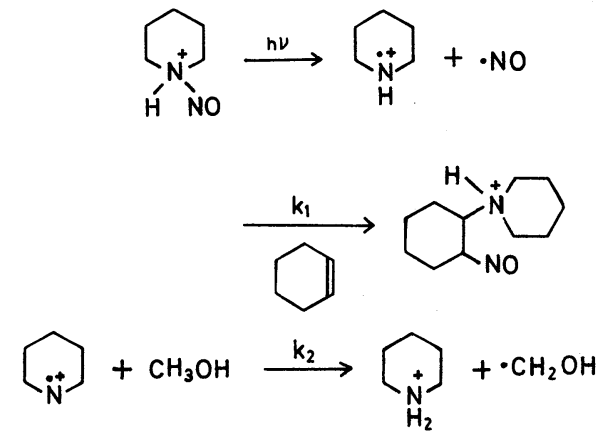

通常アンモニウミルラシカルのオレフィンに対する付 加は, $N$-クロロアミンを発生剤として行われ, 次のよう な機構が確立している ${ }^{4)}$ 。
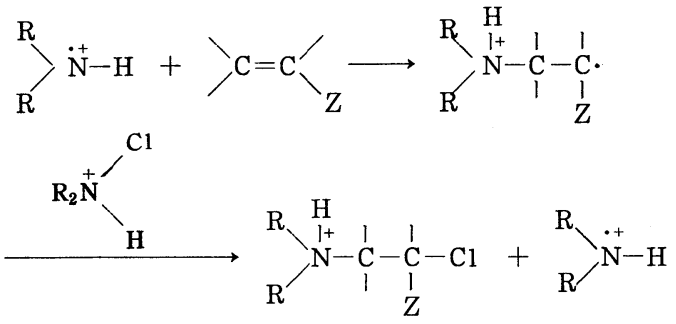

この反応は, 共役オレフィンあるいは Zが電子求引基 である場合以外は, Hofmann-Löffler反応や求電子的ク ロ口化反応が副反応として起こるために収率は低いが, $\mathrm{FeCl}_{2}$ などの金属塩を反応系に存在させると, 副反応が 除かれ収率は上がる。その場合には中性条件です $N$-ク口 ロアミンは収率よくオレフィンに付加するととが報告さ れている。てれは, 金属イオンに配位したアミニルラシ カルが生じ，その性質が強酸中のアンモニウミルラシカ ルとよく似ているためであるらと説明されている。そし て，とくにN-クロロピペリシンのシクロへキセンへの付 加においては, 酸性条件ではシス体とトランス体の混合 物が生じるのに, 中性条件ではシス体が主として生成す るととが見出されている。この立体選択性は, 次の式に

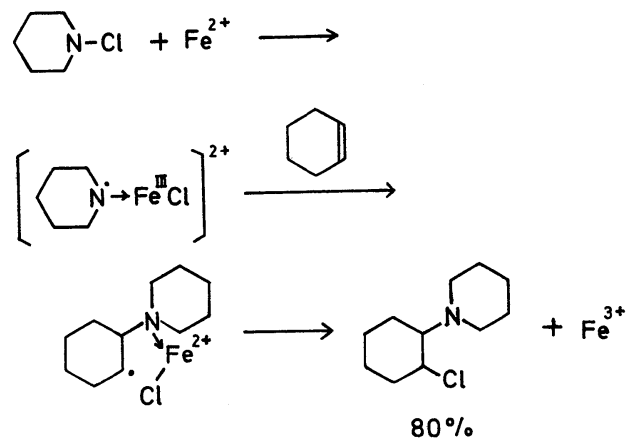


示すように，中性条件では金属イオンに配位したピペリ シニルラシカルが二重結合に付加したあと, 塩素原子の 移動が起こるためと考えられている。酸性条件では, ピ ペリシニゥミルラシ்カルが金属に配位できないので，立 体選択性が生じないのであろ $5^{72)}$ 。

アンモニウミルラシカルは, またベンゼン環にも付加 する。乙れを利用したラジル的芳香族アミノ化は, Minisciらによって精力的飞研究され $\left.{ }^{5}, 73\right)$ ，合成反応とし て確立している。たとえば，N-クロロジメチルアミンに

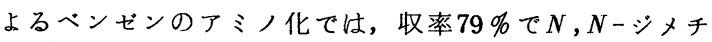
ルアニリンが得られる。
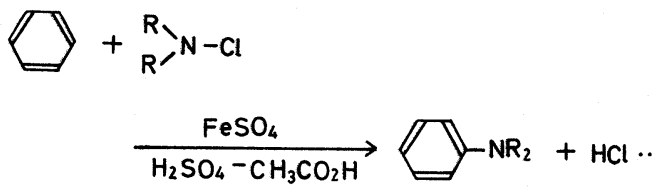

反応機構は次のように考えられている。

$$
\begin{aligned}
& \text { 開始 : } \mathrm{R}_{2} \stackrel{+}{\mathrm{N} H C l}+\mathrm{M}^{n+} \longrightarrow \mathrm{R}_{2} \stackrel{+}{\mathrm{N} H}+\mathrm{M}^{(n+1)+}+\mathrm{Cl}^{-} \\
& \mathrm{M}^{\mathrm{n}+}=\mathrm{Fe}^{2+}, \mathrm{Ti}^{3+}, \mathrm{Cr}^{2+}, \mathrm{Cu}^{+}
\end{aligned}
$$

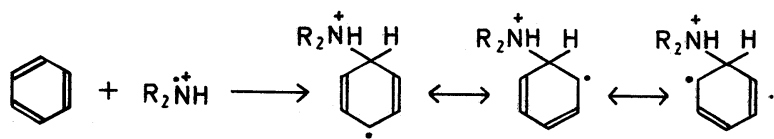

成長 :

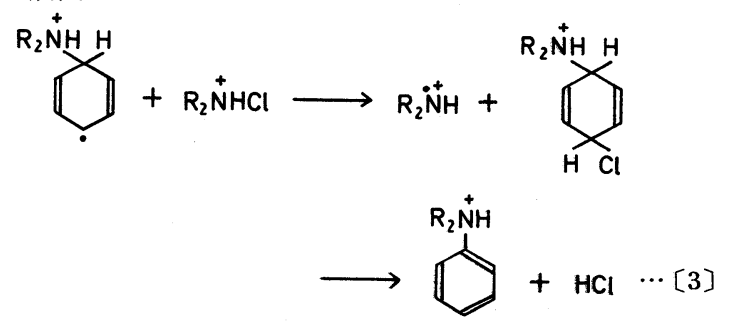

停止 : $\mathbf{R}_{2} \dot{\mathrm{N}}^{+}+\mathrm{M}^{\mathrm{n}} \longrightarrow \mathrm{R}_{2} \mathrm{NH}+\mathrm{M}^{(n+1)+} . .[4]$

ベンゼン環が電子供与基で活性化されている場合には 次の酸化反応 [5]が[3]ょりる優先的に起こる。

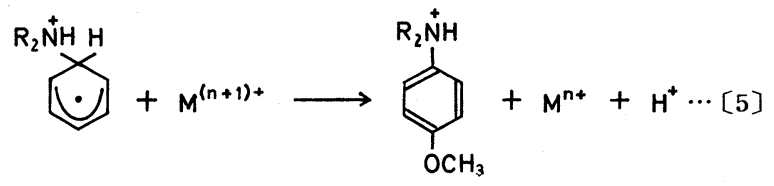

ラシカル的芳香族アミノ化の開始反応は, 酸化還元反 応以外です可能と思われるが, 報告があるのは酸化還元 反応だけである。

以上見てきたように，アミニルラシカルとアンモニウ ミルラシカルの反応性は, とくに炭素一炭素二重結合へ の付加に関して著しい違いがあるが, 最近Chow らはメ タノール中シクロヘキセン存在下の $N$-ニトロピペリジ の光分解におんては, 中性条件では水素引抜を反応に よる生成物のみが, 酸性条件ではシクロへキセンへの付 加体のみが生成するととを見出し, 中性条件では 1ーピペ リシニルラジカルが, 酸性条件ではピペリシニウミルラ ジカルが反応種であることを鮮かに示した。

3.7.その他の反応 アミニルラシカルは, ニトロ ソアミンに付加してニトロキシドを与える。たとえば, 1ーピペリシニルラジカルは，2-メチル-2-ニトロソプロ パンによりトラップされてニトロキシド（22）を生成し， このESRスペクトルが測定された 24)。

アンモニウミルラシカカルニトロソア ミンへの付加は知られていない。

アミニルラジカルと酸素之

の反応については，2,2,6,6-

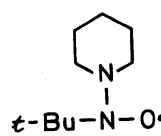

(22) テトラメチルー1ーピペリジニルラシ்カ (7) が酸素々定量的に反応して，ただちに対応す るニトロキシドを与えるてとが見出されてお り, Ingoldらはこのととから, 他のシアルキ ルアミニルラジカルす同様に酸素と反応する であろうと述べている ${ }^{48)}$ 。

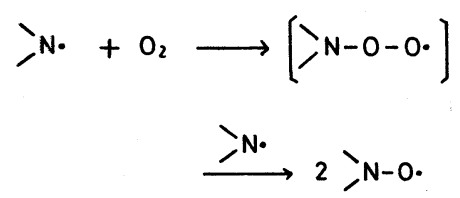

てれに関連して最近ジメチルアミニルラ ジカルと酸素との反応をオレフィンおよび塩 化亜鉊 (II) の存在下で行うと,オレフィンの エポキシ化の起とるととが, Michejda と $\mathrm{Ca}$ mpbellによって報告された ${ }^{75)}$ 。これは次のような機構で 進行すると考えられている。

$\left(\mathrm{CH}_{3}\right)_{2} \mathrm{~N}-\mathrm{N}=\mathrm{N}-\mathrm{N}\left(\mathrm{CH}_{3}\right)_{2} / \mathrm{ZnCl}$

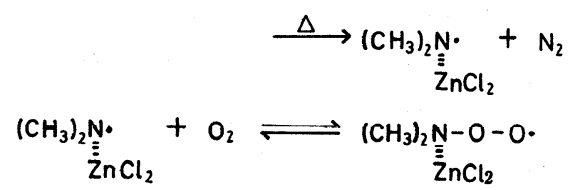


$\left(\mathrm{CH}_{3}\right)_{2} \underset{\equiv}{\stackrel{\mathrm{Z}}{\mathrm{Z}}-\mathrm{O} \mathrm{nCl}_{2}}$

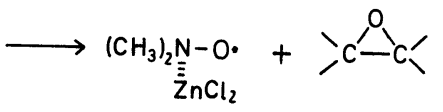

アンモニウミルラジカルと酸素との反応は知られてい ない。

（昭和 53 年 1 月 13 日受理）

\section{文献}

1) W. C. Danen, F. A. Neugebauer, Angew. Chem. internat.Edit., 14, 783 (1975)

2) Y. Miura, N. Makita, M. Kinoshita, Tetrahedron Lett., 127 (1975)

3) G. Brunton, J. F. Taylor, K. U. Ingold, J.Am. Chem. Soc., 98, 4879 (1976)

4) R. S. Neal, Synthesis, 1 (1971)

5) F. Minisci, Synthesis, 1 (1973)

6) G. Sosnovsky, D. J. Rawlinson, "Advances in Free Radical Chemistry",Vol. 4, G. H. Williams, Ed., Logos press, London, p.203 (1972)

7) H. Wieland, Liebigs Ann. Chem., 381, 200 (1911)

8) G. N. Lewis, D. Lipkin, J. Am. Chem. Soc., 64, 2801 (1942)

9) F. A. Neugebauer, S. Bamberger, Chem. Ber., 107,2362 (1974)

10) C. B. Colburn, Chem. Brit., 2, 336 (1966)

11) J. S. Watson, J. Chem. Soc., 3677 (1956)

12) F. O. Rice, C.J.Grelecki, J. Am. Chem. Soc., 79, 2679 (1957)

13) W. C. Danen, T. T. Kensler, J. Am. Chem. Soc., 92, 5235 (1970)

14) R. W. Dennis, B.P.Roberts, J. Organometal. Chem., 43, C2 (1972)

15) W. C. Danen, T. T. Kensler, Tetrahedron Lett., 2247 (1971)

16) P. Neta, R. W. Fessenden, J. Phys. Chem., 75, 738 (1971)

17) D. W. Pratt, J.J. Dillon, R. V. Lloyd, D. E. Wood, J. Phys. Chem., 75, 3486 (1971)

18) R. V. Lloyd, D.E.Wood, Mol. Phys., 20, 735 (1971)
19) N. M. Atherton, E. J. Land, G. Porter, Trans. Faraday Soc., 59, 818 (1963)

20) E.J.Land, G.Porter, Trans. Faraday Soc., 59, 2027 (1963)

21) S.N.Foner, E.L.Cochran, V.A.Bowers, C.K.Jen, Phys. Rev. Lett., 1, 91 (1958)

22) T.Toda, E.Mori, H.Horiguchi, K.Murayama, Bull. Chem. Soc. Jpn., 45, 1802 (1972)

23) O.E.Edwards, D.Vocelle, J.W.Apsimon, Can. J. Chem., 50, 1167 (1972)

24) O.E.Edwards, D.H.Paskovich, A.H.Reddoch, Can. J. Chem., 51, 978 (1973)

25) P.G.Gassman, K. Uneyama, J.L. Hahnfeld, J.Am. Chem.Soc., 99, 647 (1977)

26) E.Hedeya, R.L.Hinman, V.Schomaker, S. Theodoropulos, L.M.Kyle, J.Am.Chem.Soc., 89, 4875 (1975)

27) S.Sustmann, R.Sustmann, C.Rüchardt, Chem.Ber。, 108, 1527 (1975)

28) R.W.Lockhart, R.W.Snyder, Y.L.Chow, J. C. S. Chem. Comm., 52 (1976)

29）講座有機反応機構 $\mathbf{9}$, 島村, 右田, 稲本, 徳丸, 「游離 基反応」（上）, 東京化学同人，東京 (1969), p. 25

30) Y. Nomura, K. Ogawa, Y. Takeuchi, S. Tomoda, Chem. Lett., 693 (1977)

31) T. Cole, J. Chem. Phys., 35, 1169 (1961)

32) J. S. Hyde, E. S. Freeman, J.Phys. Chem., 65, 1636 (1961)

33) A. D. Tench, J. Chem. Phys., 38, 593 (1963)

34) W. C. Danen, R. C. Rickard, J. Am. Chem. Soc., 94, $3254(1972)$

35) J. Spanswick, K. U. Ingold, Can. J. Chem., 48, 546,554 (1970)

36) J. P. Ferris, R. D. Gerve, G. R. Gapski, J.Am. Chem. Soc., 89, 5270 (1967)

37) J. R. L. Smith, R. O. C. Norman, A. G. Rowley, J. C. S. Perkin I, 566 (1973)

38) F. Minisci, A. Citte rio, M. Perchinunno, F. Bertini, Gazz. Chim. Ital., 105, 1083 (1975)

39) Y. L. Chow, Acc. Chem. Res., 6, 354 (1973)

40) A. J. Cessna, S. E. Sugamori, R. W. Yip, M. P. Lau, R. S. Snyder, Y. L. Chow, J. Am. Chem. Soc., 99, 4044 (1977)

41) K. K. Barnes, C. K. Mann, J. Org. Chem., 32, 1474 (1967) 
42) R. N. Adams, Acc. Chem. Res., 2, 175 (1969)

43) F. A. Neugebauer, S. Bamberger, Angew. Chem. internat. Edit., 10, 71 (1971)

44）小方芳郎編著「有機過酸化物の化学」, 南江堂 (1971), p. 175 および引用文献

45) R. W. Fessenden, R. H. Schuler, J. Chem. Phys., 39, 2147 (1963)

46) R. W. Fessenden, P. Neta, J. Phys. Chem., 76, 2857 (1972)

47) R. I. Walter, J. Am. Chem. Soc., 88, 1924 (1966)

48) J. R. Roberts, K. U. Ingold, J. Am. Chem. Soc., 95, 3228 (1973)

49) J. K. Kochi, "Free Radicals", Vol.2, J. K. Kochi Ed., Wiley, New York (1973), p. 665

50) F. Minisci, R. Galli, Tetrahedron Lett., 2531 (1966)

51) E. J. Corey, W. R. Hertler, J. Am. Chem. Soc., 82, 1657 (1960)

52) M. E. Wolf, Chem. Rev., 63, 55 (1963)

53) P. Kovacic, M. L. Lowery, K. W. Field, Chem. Rev., 70, 639 (1970)

54) S. F. Nelsen, "Free Radicals", Vol.2, J. K. Kochi Ed., Wiley, New York, (1973)

55) N. H. Anderson, R. O. C. Norman, J. Chem. Soc., B, 993 (1971)

56) P. Wardman, D. R. Smith, Can. J. Chem., 49, 1869,1880 (1971)

57) B. R. Cowley, W. A. Waters, J. Chem. Soc., 1228 (1961)

58) D. Mackay, W. A. Waters, J. Chem. Soc., C, 813 (1966)

59) C. J. Michejda, W. P. Hoss, J. Am. Chem. Soc., 92, 6298 (1970)
60) J. A. Howard, "Advances in Free Radical Chemistry" Vol. 4, G. H. Williams Ed., Logos press, London (1972), p.49

61) F. Minisci, R. Galli, M. Perchinunno, R. Bernardi, Chimica e Industria (Milano), 50, 453 (1968)

62) C. Walling, A. Padwa, J. Am. Chem. Soc., 85, 1597 (1963)

63) T. Caronna, A. Citterio, L. Grossi, F. Minisci, K. Ogawa, Tetrahedron, 32, 2741 (1976)

64) F. Minisci, R. Galli, M. A. Rossetti, Chimica e Industria (Milano), 49, 947 (1967)

65) A. G. Davies, S. C. W. Hook, B. P. Roberts, J. Organomet. Chem., 22, C37 (1970)

66) A. G. Davies, S. C. Hook, B. P. Roberts, J. Organomet. Chem., 23, C11 (1970)

67) A. G. Davies, B. P. Roberts, "Free Radicals" Vol. 1, J. K. Kochi Ed.,Wiley, New York (1973)

68) K. U. Ingold, B. P. Roberts, "Free Radical Substitution Reactions", Wiley-Interscience, New York (1971), p.20, 45, 67, 145

69) R. S. Neal, N. L. Marcus, R. G. Scheppers, J. Am. Chem. Soc., 88, 3051 (1966)

70) A. Good, J. C. J. Thynne, J. Chem. Soc., B, 684 (1967)

71) J. M. Surzur, L. Stella, P. Tordo, Tetrahedron Lett., 3107 (1970)

72) F. Minisci, Acc. Chem. Res., 8, 165 (1975)

73) F. Minisci, Topics in Current Chemistry, 62, 1, Springer-Verlag (1976)

74) S. Shih, R. J. Buenker, S. D. Peyerimhoff, C. J. Michejda, J. Am. Chem. Soc., 94, 7620 (1972)

75) Chem. Eng. News, 1976, Sept. 13, p.18 